\title{
A túlélók mindennapjai. A hospice-ellátásban dolgozók életminősége
}

\author{
Révay Edit dr..$^{1,2}$. Kegye Adrienne dr. ${ }^{3}$ \\ Zana Ágnes dr. ${ }^{3}$. Hegedús Katalin dr. ${ }^{3}$ \\ ${ }^{1}$ Sapientia Szerzetesi Hittudományi Főiskola, Szociológia Tanszék, Budapest \\ ${ }^{2}$ Központi Statisztikai Hivatal, Népességtudományi Kutatóintézet, Budapest \\ ${ }^{3}$ Semmelweis Egyetem, Általános Orvostudományi Kar, Magatartástudományi Intézet, Budapest
}

\begin{abstract}
Bevezetés: A hospice-szolgálatok és az általuk ellátott végstádiumú betegek száma évről évre emelkedik, ugyanakkor az itt dolgozó szakemberek száma csökken. Testi és lelki megterhelésük fokozódik, ez pedig kiégéshez és a dolgozók fluktuációjához vezethet. Célkitüzés: A hospice-okban dolgozók testi és lelki állapotának, a kiégéssel kapcsolatos veszélyeztetettségüknek és megküzdési stratégiáiknak felmérése. Módszer: A Hungarostudy vizsgálatokra alapozott kérdőíves felmérés hospice-szakemberek és önkéntesek $(\mathrm{n} \cong 1500)$ körében. Eredmények: A kérdőívet kitöltőknek $(\mathrm{n}=$ 195 ) átlagban 1,86 munkahelye van, és $45,8 \%$-uk napi 12 vagy ennél több órát dolgozik. Leggyakrabban fáradtsággal, energiahiánnyal $(65,1 \%)$, zavaró testi fájdalmakkal $(46,9 \%)$, alvási $(42,1 \%)$ és emésztési problémákkal $(35 \%)$ küzdenek, túlsúlyosnak ítélik magukat $(56,9 \%)$, és lefekvéskor is munkahelyi gondjaik foglalkoztatják őket $(72,8 \%)$. Következtetések: A hospice-ban dolgozók túlterheltek, fizikai és lelki tüneteik vannak, körükben is jellemző az együttérzésből fakadó kifáradás (compassion fatique), ugyanakkor jelentősen hat az együttérzésből fakadó elégedettség (compassion satisfaction) is, mint a gondozásért kapott elismerés elfogadásának képessége. Orv. Hetil., 2016, $157(25), 1000-1006$.
\end{abstract}

Kulcsszavak: hospice-palliatív ellátás, életvégi ellátás, burnout, együttérzésből fakadó kifáradás, együttérzésből fakadó elégedettség

\section{The everyday life of survivors. The quality of life of hospice workers}

Introduction: Each year, the number of hospice services and terminally ill patients increase while the number of hospice workers is falling. The intensification of the physical and mental burdens of the latter can lead to burnout and the fluctuation of the workers. Aim: The aim of the authors was to survey the physical and mental state of hospice workers, as well as the risk of burnout and coping strategies. Method: A questionnaire survey in hospice experts and volunteers $(\mathrm{n} \cong 1500)$ based on the Hungarostudy survey was performed. Results: Those who filled in the questionnaire $(n=195)$ had on average 1.86 workplaces and $45.8 \%$ of them reported working 12 or more hours a day. Most often, they suffered from lack of energy (65.1\%), disturbing physical pain (46.9\%), sleeping (56.9\%) and digestion (35\%), they considered themselves overweight $(56.9 \%)$ and they were occupied with work problems even at bedtime (72.8\%). Conclusions: Hospice workers are overloaded, they have physical and mental symptoms and they are characterized by compassion fatigue. At the same time, they are also characterized by compassion satisfaction as an ability to accept appreciation for the caretaking.

Keywords: hospice and palliative care, end of life care, burnout, compassion fatigue, compassion satisfaction

Révay, E., Kegye, A., Zana, Á., Hegedüs, K. [The everyday life of survivors. The quality of life of hospice workers]. Orv. Hetil., 2016, 157(25), 1000-1006.

(Beérkezett: 2016. március 3.; elfogadva: 2016. április 14.)

\section{Rövidítések}

$\mathrm{CF}=$ (compassion fatique) együttérzésből fakadó kifáradás; $\mathrm{CS}$ $=($ compassion satisfaction $)$ együttérzésból fakadó elégedettség
A súlyos betegekkel foglalkozó egészségügyi dolgozók mérhetően nagyobb testi-lelki megterhelésnek vannak kitéve a más egészségügyi területeken dolgozókhoz, il- 
letve a nem egészségügyben dolgozókhoz viszonyítva. A Semmelweis Egyetem Magatartástudományi Intézetében 2000 óta folynak kutatások ennek felmérésére, elsősorban a Hungarostudy vizsgálatokra alapozva, különböző szakmák összehasonlításában [1-5]. 2013-ban elindított új kutatásunkban a hospice-okban dolgozó egészségügyi személyzet testi és lelki állapotát, a kiégéssel kapcsolatos veszélyeztetettségüket és megküzdési stratégiáikat térképeztük fel. Az elmúlt két évtizedben a hospice-szolgálatok száma évrôl évre növekedett, az egész országra kiterjedő hálózat jött létre. A jelenlegi kutatásban lehetőségünk nyílik az egész hospice-hálózatot és ezáltal az egész Magyarországot lefedő mintán vizsgálni a súlyos betegekkel foglalkozó egészségügyi dolgozók testi és lelki állapotát. Ez egy nagy létszámú, a fizikai, mentális és lelki megterhelés szempontjából homogén, ugyanakkor sok szakmát magába foglaló minta.

Az éves hospice-jelentéseket összehasonlítva arra a következtetésre jutottunk, hogy a gyarapodó hospice-szolgálatok által ellátott betegek létszáma is folyamatosan emelkedik, ugyanakkor az orvosok, az ápolók és a többi szakember száma csökken. Az 1500 szakember 2014ben több mint 8800 végstádiumú beteget látott el. Ez okozhatja, hogy a dolgozók testi és lelki megterhelése fokozódik, ami hamarabb vezethet fizikális, pszichés és szociális tünetek kialakulásához, kiégéshez, ez pedig, sajnos, növelheti a dolgozók elvándorlását, fluktuációját. Egy másik jelenség, ami a megküzdés hiányosságaira, kiégésre is utalhat, hogy az egyik hospice-osztály munkatársai jelezték: az elmúlt években összesen 150 kg-ot híztak. Ezt különösen intő jelnek tekintettük.

A témához kapcsolódó nemzetközi szakirodalom áttekintésének [6] egyik nagy hozadéka az együttérzésból fakadó kifáradás és az együttérzésből fakadó elégedettség (compassion fatique - CF és compassion satisfaction CS) fogalmának részletes áttekintése volt. Súlyos betegek ellátása során az együttérzés - „mások szenvedésének elviselése" [7] -, a traumatizált beteg helyzetébe való belefeledkezés kifáradáshoz vezethet. A CF-et a poszttraumás stresszbetegséghez hasonlítják, azzal a különbséggel, hogy mások traumájának hatására jelentkezik, ezért úgy jellemzik, mint a gondoskodás árát. Jellemző tünetei a beteggel kapcsolatos folyamatos izgatottsági állapot, distressz, alvászavar, fizikális és érzelmi fájdalmak, kimerültség. Nővéreket vizsgálva azt találták, hogy a tünetek ellenére is folytatják a betegekkel való törődést, nem engedik, hogy ezt mások is észrevegyék [8]. Míg a kiégés a szakirodalom szerint elsősorban az egészségügyi dolgozó és munkahelyi környezet kölcsönhatásából fakad, addig az együttérzésből eredő kifáradást a beteg és az egészségügyi dolgozó kapcsolatából eredő stressz eredményeként írják le. A haldoklókat gondozók mindkettőnek ki vannak téve.

Phelps és mtsai szerint az együttérzésből fakadó elégedettség (CS) azokra vonatkozik, akik pozitív élményként élik meg az ápolást. Egyszerúen kifejezve: a CS „az ápolásért kapott elismerés elfogadásának képessége" [6].

Az együttérzésből eredő kifáradással való megküzdésben, hasonlóan a kiégés megelőzésében és kezelésében a személyes stratégiák közül nagyon hangsúlyosnak találták a munka és magánélet egyensúlyának fenntartását, kiemelték a megfelelő mennyiségű alvás, helyes táplálkozás, rendszeres sport, masszázs, a humor és a különböző technikák, mint a meditáció, relaxáció, önreflexió szerepét. Az intézményi stratégiák között szerepelt a megfelelő arányú szabadság, a személyes tudatosság, közösségi rituálék fejlesztése. Itt is nagy hangsúlyt kapott a felettesi támogatás és az érzelmekkel való megbirkózás lehetőségének biztosítása, elsősorban csoportos szupervízió/ esetmegbeszélés formájában [8].

Kutatásunk távolabbi célja az eddigi oktatási és munkahelyi támogatási rendszerek továbbfejlesztése, a megfelelő támogatási programok kialakítása, amelyhez hatékony segítséget adhat a multidiszciplináris team tagjainak vizsgálata: a speciális megterhelések feltérképezése, a szakterületek közötti hasonlóságok és különbözőségek felderítése, összevetve a homogén szakmacsoportok és az egészségügy más területein tevékenykedők és a nemzetközi kutatások adataival.

\section{Módszer}

A 2013-2014-ben elvégzett empirikus felvételünkben - az eredmények összehasonlíthatósága érdekében elsősorban a korábban lezajlott magyarországi életminőség-kutatásokban - Hungarostudy 2002, 2006, 2013 - szereplő kérdőíveket használtuk a későbbi összehasonlítást is lehetővé téve: WHO Általános Jóllét Index, Rövidített Vitális Kimerültség Kérdőív, Társas Támogatás kérdőív, Beck Depresszió Kérdőív rövidített változata, Életesemények Skála, Önbizalom (Énhatékonyság vagy kompetencia) kérdőív, Erőfeszítés-jutalom-egyensúlytalanság kérdőív, Életcél Kérdőív, Rövidített házastársi stressz skála, Rövidített stressz és megküzdés kérdőívből a koherenciaérzés skála, Észlelt stressz kérdőív (PPS), Elégedettség skála [9-11]. Továbbá az egészségi állapot önbecslésére, a betegségekre vonatkozó kérdések, demográfiai kérdések (nem, kor, iskolai végzettség) és a családi állapotra vonatkozó kérdések - újabb, a társtalanság-társasság pontosabb mérésére vonatkozó kategóriákkal kiegészítve - kerültek a kérdőívbe.

A Hungarostudy kérdőívekben nem szereplő Multidimenzionális Halálfélelem Skálát is felvettük [12]. A kérdéssort saját - elsősorban a hospice-ban betöltött munkakört, a hospice-szolgálatban eltöltött időt, a kiégést megelőző, haláleseményt feldolgozó egyéni és munkahelyi módszereket, a hospice-teamen belüli kapcsolódási viszonyokat és a paraszolvenciamentesség elvével való egyetértés mértékét vizsgáló - kérdéseinkkel egészítettük ki. 
A kérdőív egy professzionális, a kutatás érvényességéhez szükséges technikai feltételeket biztosító, licencdíjjal terhelt kérdőívszerkesztővel készült, amely a http:// www.online-kerdoiv.com felületen érhető el.

Az adatgyưjitést 2013 őszétől 2014 tavaszáig, hospiceban dolgozó orvosok, ápolók, koordinátorok, gyógytornászok, pszichoszociális és egyéb szakemberek körében végeztük. A kutatás időszakában, 2013-ban összesen 1562 fó dolgozott a hospice-okban (önkéntesekkel együtt), 2014-ben pedig 1537. A felmérésben való részvételt önkéntes alapon kértük, és a válaszadóknak teljes anonimitást biztosítottunk. A kérdőívhez alapvetően online hozzáférést biztosítottunk, de hospice-képzések és -konferenciák során - a minél nagyobb minta reményében - nyomtatott formában is elérhetővé tettük. Mivel a kérdezettek köre zárt, kutatásunk esetében az online adatfelvétellel szembeni ellenérvek közül számos kizárható. A felmérés során beérkezett adatokat SPSS.22 es adatelemző programmal dolgoztuk fel. A kutatás etikai engedélyének száma: 274/2013 (TUKEB).

\section{Eredmények}

Jelen tanulmányunkban a gazdag anyagból csak a legszembetűnőbb eredményeket ismertetjük. A válaszadók száma 207 fó volt, ebből érvényesen 195 fó - 16 férfi és 179 nő - töltötte ki a kérdőívet. Életkorukat tekintve válaszadóink átlagéletkora 46,04 év (a legfiatalabb 23 éves, a legidősebb 76 éves, az átlagtól való eltérés:

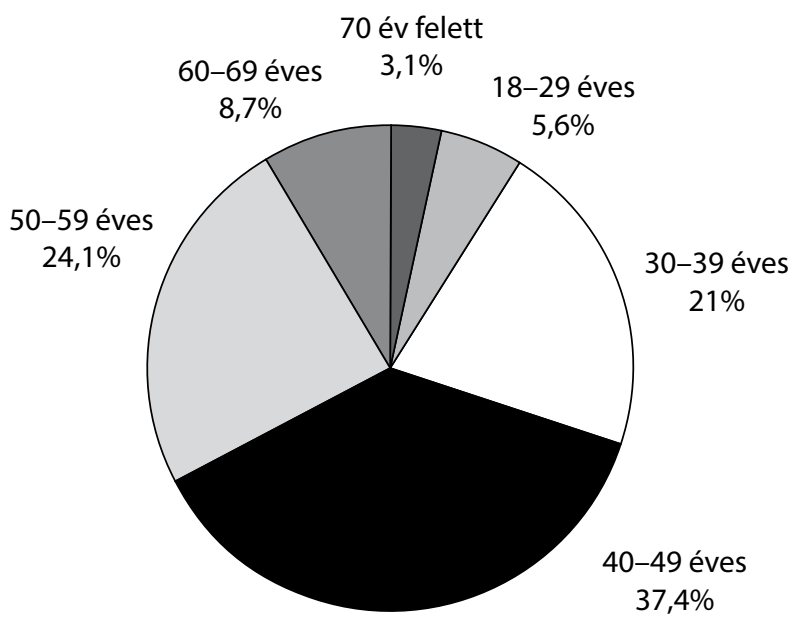

1. ábra | A kérdőívet kitöltók életkor szerinti megoszlása $(\mathrm{N}=195)$

10,76882). Legtöbben a 40-49 éves korcsoportból kerültek ki (1. ábra).

Egészségügyi vagy szociális szakemberként valamely hospice-intézmény alkalmazásában állt 134 fő (68,7\%), 60 fó (30,8\%) önkéntes volt. Ez a kitöltői arány azt mutatja, hogy míg az önkéntesek (60/200) majdnem egyharmada, az alkalmazásban lévő hospice-munkatársaknak (134/1500) csupán 10 százaléka válaszolt a
1. táblázat | Önkéntes vagy fizetett alkalmazott a hospice-ban? $(\mathrm{N}=183)$

\begin{tabular}{lcc}
\hline Összevont munkakör & Fizetett & Önkéntes \\
\hline Orvos & $9(6,8 \%)$ & $4(8 \%)$ \\
$\begin{array}{l}\text { Pszichológus, lelkész, lelkigondozó, } \\
\text { mentálhigiénés, pszichoterapeuta }\end{array}$ & $12(9 \%)$ & $12(24 \%)$ \\
$\begin{array}{l}\text { Koordinátor, adminisztrátor } \\
\text { Ápoló (diplomás, hospice-szak, egyéb }\end{array}$ & $76(57,1 \%)$ & $5(10 \%)$ \\
$\begin{array}{l}\text { szak, ápolási asszisztens) } \\
\text { Szociális munkás, foglalkozásterapeuta }\end{array}$ & $9(6,8 \%)$ & $6(12 \%)$ \\
$\begin{array}{l}\text { Gyógytornász, dietetikus } \\
\text { Önkéntes segítő, nem egészségügyi } \\
\text { végzettségú, nem segítő foglalkozású }\end{array}$ & $11(8,3 \%)$ & 0 \\
\hline \begin{tabular}{l} 
Összesen \\
\hline
\end{tabular} & 133 & $21(42 \%)$ \\
\hline
\end{tabular}

kérdésekre. A hospice-szolgálatban fizetett munkatársként részt vevő munkatársak és önkéntesek arányát az 1. táblázat mutatja.

Az együttérzésból egyaránt fakadhat kifáradás vagy elégedettség is, és az egyik legérintettebb csoport a tartósan súlyos betegekkel és haldoklókkal foglalkozó egészségügyi dolgozók köre. A hospice-ban fizetett alkalmazottaknak átlagban 1,86 munkahelyük van, és $45,8 \%$-uk napi 12 órát vagy ennél többet dolgozik. Heti 36 vagy ennél több órát 37,4\%-uk tölt életvégi ellátással. A válaszadók 47,2\%-a 1-4 éve, 29,7\%-a 5-9 éve, 13,8\%-a 10-19 éve dolgozik hospice-ban.

A kifáradást előre jelző, illetve következményes tünetek közül válaszadóink leggyakrabban fáradtsággal, energiahiánnyal $(65,1 \%)$, zavaró $(46,9 \%)$, a mindennapi tevékenységben korlátozó $(32,9 \%)$ testi fájdalmakkal (fóként derék-, hát-, végtag-, ízületi és fejfájás) és alvással $(42,1 \%)$, emésztéssel kapcsolatos (például puffadás, hányinger, gyomorfájás, hasmenés) problémákkal (35\%) küzdöttek (2. ábra). A foglalkozási csoportok közül az ápolók jelezték a legtöbb egészségügyi problémát: derék- és hátfájás $(74,1 \%)$, kar-, láb-, ízületi fájdalmak $(64,6 \%)$, szédülés $(26,5 \%)$. Őket korlátozza legnagyobb arányban fájdalmuk a mindennapi tevékenységekben $(44,5 \%)$.

Az életkor és a hospice-szolgálatban eltöltött évek számának növekedésével együtt növekszik a felvétel előtti évben leggyakrabban megjelölt öt betegség - magas vérnyomás, allergia, reuma és más izom- és csontrendszeri panaszok, gyomor- és bélrendszeri, valamint pszichiátriai betegségek - valamelyikével terheltek aránya. Az 5-9 éve hospice-ban dolgozók 21\%-a jelezte, hogy gyomor-bél rendszeri betegsége van, a 10-19 éve ott dolgozók esetében ez az arány már 30,8\% volt. A pszichiátriai betegséggel küzdők aránya is 7\%-ról 11,5\%-ra nőtt.

A nem adaptív megküzdés egyik elterjedt formája az evés, mint orális örömforrás révén szerzett megnyugvás. Emellett a magyar társadalomban ismert kockázati faktor az elhízás. 


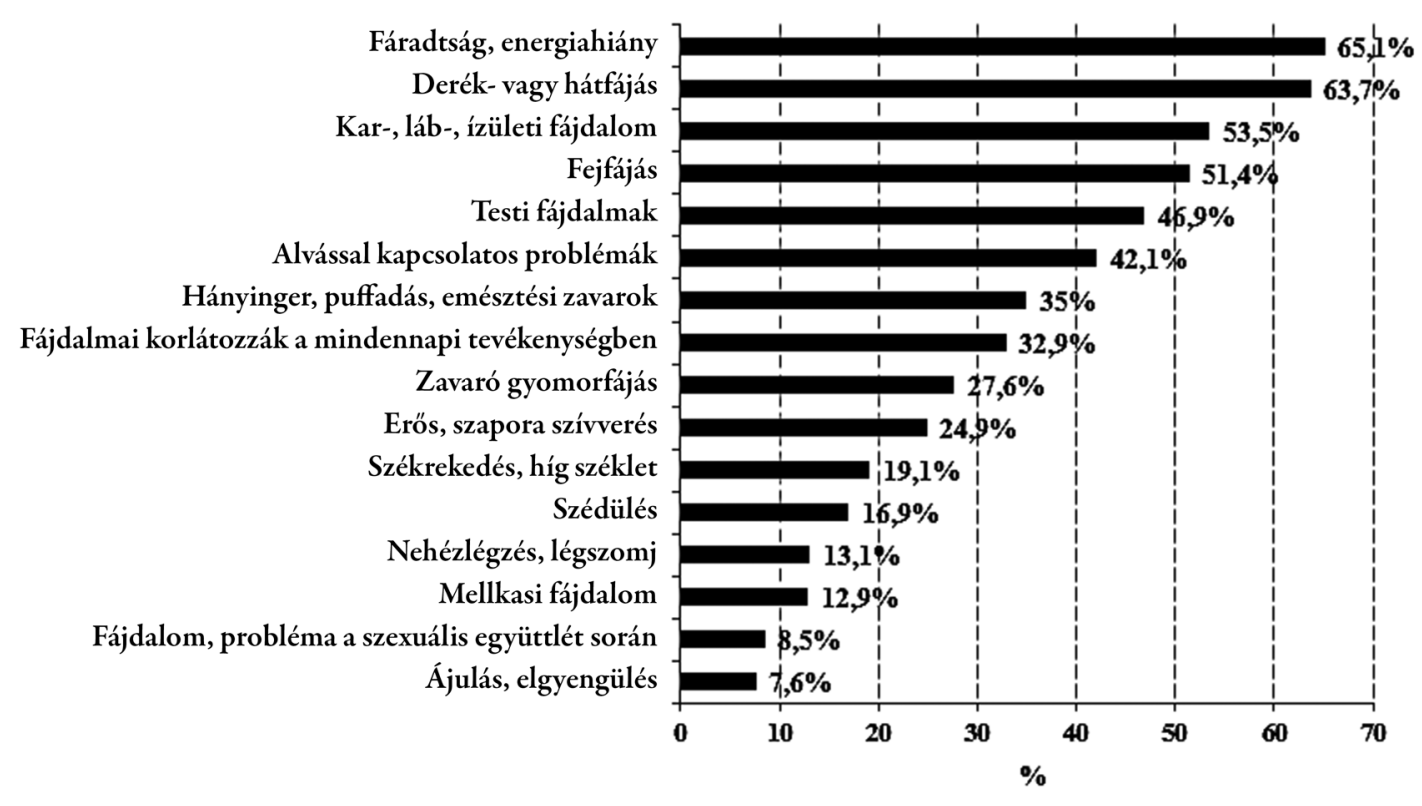

A 2014-es Európai Lakossági Egészségfelmérés eredményei szerint Magyarország felnőtt lakosságának 54\%-a túlsúlyos vagy elhízott [13]. A mintánkban szereplő válaszadók 56,9\%-a túlsúlyosnak ítéli magát. A megkérdezettek közül, akik híztak, összesen 553 kilogrammal gyarapodtak, akik veszítettek súlyukból, összesen 183 kilogrammal lettek könnyebbek. Összességében a válaszadók 370 kilogrammal gyarapodtak, amióta a hospiceban tevékenykednek. A súlyváltozás és a hospice-szolgálatban eltöltött évek száma közötti összefüggést vizsgálva azt észleltük, hogy a pozitív vagy negatív irányban történt - 5 kilogrammot meg nem haladó - súlyváltozás többnyire a hospice-szolgálat első négy évében történt. A válaszok között egészen extrém súlygyarapodással is találkoztunk, az 5 kilogramm fölött hízók igen széles skálán - 6 és $40 \mathrm{~kg}$ között - mozogtak.

A halálesetek feldolgozási módjának kiválasztása nagyban függ a személyiségtôll és a mintáktól. A kitöltők válaszainak feldolgozása után a halálesetkor gyakorolt önvigasztalások gyakoribb módozatait típusokba rendezve azt találtuk, hogy a válaszadók többsége $(67,8 \%)$ adaptív megküzdést gyakorol, míg a nem adaptív megküzdéssel élók aránya $32,2 \%$. Az adaptívan megküzdők a közösség, társ (család 33,8\%, barátok 30,8\%) megtartó erejére támaszkodva távolodnak el a halálesetektôl. Szintén a közösség segítségével küzd meg az empatikusan hallgató társsal, barátokkal, munkatársakkal ventilálva a dolgozók 24,1\%-a. A nem adaptív megküzdők soron kívül rágyújtanak vagy - bár nem éhesek - mégis esznek, esetleg munka után, noha nem tervezték, vásárolnak valamit (3. ábra). A jelzett súlygyarapodáson túl és azzal összefüggésben az is a nem adaptív megküzdésre enged következtetni, hogy míg a válaszadók több mint fele túlsúlyosnak érzi magát, addig a válaszok között a közösségben vagy egyénileg végzett sport, mozgás, utazás csak 9,7\%- ban szerepelt. Az adaptív megküzdési módokat még mindig inkább csak - egyénileg, gyakran egyedül gyakorolt - feszültségoldó, figyelemelterelő távolságvételként jelölték meg: „lazítás”, filmnézés, olvasás, zenehallgatás és természetjárás (12,3\%), az élet öröme, mozgalmasságának élvezete $(3,1 \%)$, alkotótevékenység ( $1,5 \%)$. A szupervízió aránya $6,2 \%$ volt.

Az adaptív és a nem adaptív halálesemény-feldolgozási módok megjelölésének aránya jelentős eltérést mutatott, ha a családi állapotok szerint vizsgáltuk. Családi állapotukat tekintve a válaszadóknak $51,8 \%$-a házas és házastársával él, 20\%-a sosem volt még házas, 22,6\%-a pedig elvált.

A szokottnál jóval több válaszlehetőséget kínáltunk a válaszadóknak: a jogi kategóriák helyett a megélt tényleges társas-társtalan állapotukat tudták megjelölni. Ezeket a kategóriákat három összefoglaló kategóriába soroltuk:

l. van társa és együtt élnek;

2. van társa, de nem élnek együtt;

3. nincs társa.

Nagy eltérés mutatkozott, és ez tovább árnyalta a társas támogatottság védőerejének kérdését. Adataink szerint ugyanis azok részesítik előnyben nagyobb arányban a

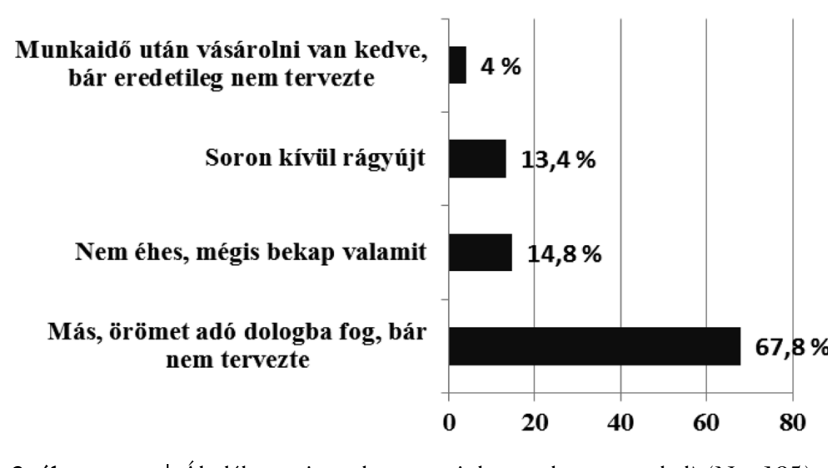

3. ábra $\mid$ Általában mit szokott tenni, ha egy beteg meghal? $(\mathrm{N}=195)$ 
nem adaptív megküzdési módokat, akiknek ugyan van társuk, de nem élnek együtt. E kategóriába tartozók $40 \%$-a mondta, hogy ha meghal egy betege, akkor, ha nem is éhes, de bekap valamit, és 30\%-uk soron kívül rágyújt és csak 30\%-uk választ adaptív feloldást. A társsal együtt élők - függetlenül attól, hogy házasok vagy élettársak - esetében igazolódik a társ létének védőfunkciója, azaz náluk elsöprő többségben az adaptív megküzdés múködött $(73,1 \%)$.

Az orvoslás, betegápolás, segítő szakmák mind empátiát követelő hivatások, ám a helyes megküzdés, az egészséges távolságvétel elengedhetetlen a kiégés megelőzésében [14]. Ennek biztos jelei, ha a szakembereket ébredéskor és lefekvéskor nem a munkahelyi gondjaik foglalkoztatják, és/vagy ha hazaérve félre tudják tenni azokat. Válaszadóink többségét $(72,8 \%)$ még lefekvéskor is a munkahelyi gondjai foglalkoztatják, ébredéskor csupán 46,2\%-uk érzi magát kipihentnek, frissnek, és csak $57,4 \%$-uk volt nyugodt és ellazult, miközben a válaszadók 49,7\%-a azt állította, hogy hazaérve ellazulnak és félreteszik a munkahelyi gondjaikat. Ez lehet látszólagos ellentmondás: az otthoni feladatok egy időre elterelhetik a figyelmet a szakmai problémákról, de ezek a pihenés óráiban újra felszínre törhetnek. A fenti adatok együttesen a kifáradás és a túlzott involválódás veszélyét jelezhetik.

Az életerő, életkedv ugyancsak a kiegyensúlyozott lélek sajátjai. A kitöltők 72,2\%-a ítélte úgy, hogy napjai tele voltak érdekes dolgokkal, 83\% aktívnak és élénknek, $80,5 \%$ vidámnak és jókedvűnek érezte magát, vagyis úgy érzi, tele van vitalitással, érdeklődőek és pozitívak. Válaszadóink 67,4\%-át hite és értékei vezérlik mindennapjaiban, 66,7\%-uk felfedezi az élet örömeit, 66,1\%-uk értékeli és örül, hogy biztos a munkahelye, és 58,1\%-uk képes megbocsátani önmagának és másoknak. Ezek az adatok is mutatják, hogy a világgal és önmagukkal alapvetően harmóniában vannak még akkor is, ha csupán 47,1\%-uk elégedett a munkájával, sőt ennél jóval kisebb arányban, mindössze 16,5\%-uk elégedett anyagi helyzetével. Ennek ellenére a megkérdezettek 72,7\%-a nem szeretne a hospice szigorú paraszolvenciaelvén változtatni. Ezt az elköteleződést mutatja az is, hogy a megkérdezettek 17,5\%-a már több mint 10 éve, további 31,9\%-a már 5-9 éve hospice-ban dolgozik, és a válaszadók $55,7 \%$-a évtizedekig, amíg csak képes rá, szeretne is ott dolgozni.

\section{Megbeszélés}

A nemzetközi szakirodalom áttekintésekor azt találtuk, hogy kevés a súlyos betegekkel foglalkozó egészségügyi dolgozók testi és lelki állapotát felmérő és a más egészségügyi dolgozókkal összehasonlító - különösen a magyar vizsgálatokhoz hasonló, átfogó - kutatás. A multidiszciplináris team állapotának komplex elemzése pedig különösen ritka. A kutatási eredményeket publikáló közleményekben szintén nagyon alacsony azon közlemé- nyek száma, ahol a kutatásba bevont minta nagyobb $(\mathrm{n}=$ 117-630) [6].

A kutatás korlátait vizsgálva felmerült, hogy az online kérdőíves vizsgálatok módszertana még jórészt kidolgozatlan és számos szakmai-módszertani kérdést vet fel. Ennek feltételezett okai:

1. a lakosság számítógéppel, internet-hozzáféréssel való korlátozott ellátottsága;

2. a mintavétel lehetőségének megoldatlansága;

3. az interneten ingyenesen elérhetô kérdőívszerkesztő programok kezdetlegessége és a kutatásetikai és kutatásérvényességi feltételek biztosításának nehézségei.

Jelen kutatás során igyekeztünk kiküszöbölni ezeket a nehézségeket azzal, hogy a kutatás érvényességéhez szükséges technikai feltételeket biztosító, licencdíjjal terhelt professzionális online kérdőívszerkesztő szoftvert használtunk. Továbbá több csatornán is jól elérhető populáción kérdőíveztünk, teljes körú volt a vizsgálatba bevont populáció, a mintába kerülést csupán a válaszadási hajlandóság határozta meg.

A válaszadói hajlandóságot vizsgálva láthatjuk, hogy a hospice-okban dolgozó 1500 fơből 207-en töltötték ki a kérdőívet, ezen belül is az önkéntesek aránya magas. A válaszadók jelentős része szakdolgozó, míg az orvosok száma igen alacsony. Felmerül a kérdés: vajon ez esetben is szerepet játszik-e a korlátozott internetelérés, ami egyben az információ áramlásának is gátja lehet, illetve mennyire befolyásolja a dolgozók válaszadói kedvét, hogy túlterheltek, egyszerre több munkahelyen dolgoznak, figyelmük fókuszában a betegek, családtagjaik állnak és kevésbé saját testi, lelki egészségük.

Jelenlegi kutatási eredményeink feldolgozásakor és a korábbi kutatásokkal való összehasonlításakor azt találtuk, hogy azok több ponton megegyeznek. 2004-ben publikált kutatásunkban, amelyben 200, súlyos betegekkel foglalkozó egészségügyi dolgozó testi és lelki állapotát vizsgáltuk a mostanihoz hasonló mérőeszközökkel, sokkal több ápoló $(58,85 \%)$ panaszkodott fájdalmakra, mint orvos $(40 \%)(\mathrm{p}<0,05)$. Arra a kérdésre, hogy állt-e kezelés alatt élete során bizonyos betegségek miatt (daganatos betegség, depresszió, magas vérnyomás, gyomorbetegség), a súlyos betegekkel foglalkozó egészségügyi dolgozók 46,5\%-a válaszolt igennel, szemben a nem egészségügyiek 27,3\%-ával. A depressziós megbetegedés szignifikánsan magasabb volt ebben a csoportban a nem egészségügyi dolgozókhoz $(\mathrm{p}=0,000)$ viszonyítva. A megküzdési stratégiákat is figyelembe véve sokkal többen dohányoztak a nem egészségügyi dolgozókhoz viszonyítva (37,9\%, illetve 24,6\%). A családi állapotot tekintve a súlyos betegekkel foglalkozó ápolók körében jóval nagyobb volt az egyedülállók, az elváltak aránya, mint az orvosok és az egyéb diplomás egészségügyiek körében: a legnehezebb területen dolgozó ápolóknak alig fele $(54,6 \%)$ rendelkezett viszonylag kiegyensúlyozott családi háttérrel és 45,3\%-uk volt egyedülálló, elvált vagy özvegy [2]. 
Tovább árnyalta viszont a képet, amikor a hospiceápolók és gerontológai ápolók $(\mathrm{N}=74)$ adatait hasonlítottuk össze. Az idős betegeket ellátó ápolók munkahelyistressz-értéke nagyobb volt, mint a haldokló betegekkel foglalkozó hospice-ápolóké $(\mathrm{p}<0,05)$. Társas támogatottságuk tekintetében a hospice-ápolók kedvezőbb helyzetűek voltak, mint az idős betegeket ellátók $(\mathrm{p}=0,048)$, elsősorban a munkahelyi társas támogatás tekintetében, ami a jó csapatszellemnek volt köszönhető, és növelte a hospice-dolgozók elégedettségét [3].

Hasonló eredményre jutott egy lengyel vizsgálat is, amely szerint a hospice-ban dolgozók kevésbé kiégettek, mint más ápolók, ami a jobb munkakörülményeknek, illetve a munkahelyi támogatásnak köszönhető [15].

Jelen adataink - összhangban a korábbi kutatások eredményeivel - azt jelzik, hogy válaszadóink a kifáradás és kiégés felé vezető tünetektől - energiahiánytól, fáradtságtól, testi-lelki fájdalmaktól, betegségtől, alvási és regenerálódási problémáktól, túlsúlytól - szenvednek. Ugyanakkor az együttérzésből fakadó elégedettséget támogató tényezők is erőteljesen múködnek: munkájukat érdekesnek találják, aktívak, jókedvűek, érdeklődőek, és hosszú távon szeretnék folytatni munkájukat.

Az adaptív-inadaptív megküzdés adatait elemezve azt is felfedezhetjük, hogy a kedvezőtlenebb stratégiák például dohányzás, nem tervezett étkezés, vásárlás - alacsonyabb százalékban jelentek meg vizsgálatunkban. A válaszadók általános állapotukat jónak ítélték, a család, közösség, azon belül a munkahelyi közösség védő, megküzdést segítő szerepét a jelen kutatás adatai is megerősítették. A feldolgozás folyamatát támogatja, hogy lelkiismeretük szerint mindent megtettek a beteg szenvedésének enyhítéséért és erről visszajelzéseket is kapnak a hozzátartozóktól, valamint az a meggyőződés, hogy az elhaltak már nem szenvednek tovább. Hozzátartozik az a tapasztalat is, hogy a hospice-munka önmagában is jutalmazó attitûddel bír: sok esetben idealizált, a közösség által felértékelt, tisztelt volta a hospice-ban dolgozók énerejét növeli. Mégis, más adatok felvetik a súlyos betegekkel dolgozók veszélyeztetettségét. A fentebb említett tüneteken túl azt találtuk, hogy a kifáradás és a kiégés megelőzését szolgáló adaptív megküzdési módok szúk palettáját ismerik és ezeket is elsősorban egyedül, illetve családjuk körében alkalmazzák. A társas tevékenységek kevésbé jelentek meg, ami szintén a túlterheltségre utalhat.

A fentebb említett kutatások [3, 15] adataival ellentétben jelen vizsgálatunk - és gyakorlati tapasztalataink alapján a szupervízió alkalmazása elenyésző. E jelenség hátterében nem annyira a szupervízió minősége vagy szükségességének megkérdőjelezése áll, mint inkább az, hogy nehezen hozzáférhető, illetve, hogy sokaknak le kell küzdeniük a szupervízióval szembeni ellenállásukat. Ugyanakkor a gyakorlati tapasztalatok azt mutatják, hogy a dolgozók leterheltsége, időhiánya, a jellemzően két-három munkahely és a munka-család arányok eltolódása is hozzájárulhat az alacsonyabb részvételi kedvhez.
Ezt alátámasztja az a tapasztalatunk is, hogy a képzésekbe épített kommunikációs, önismereti tréningeken, esetmegbeszélési lehetőségeken a résztvevők aktívak és jelentőségével egyetértenek.

\section{Következtetések}

Kutatásunk kezdeti eredményei azt mutatják, hogy a hospice-munkatársak összességében elégedettek, munkájukat hivatásként élik meg és hosszabb távon szeretnének hospice-ban dolgozni, mégis a munkakörülményekben, anyagi téren és az egyéni és intézményi támogatási rendszerekben jelentkező nehézségek fokozottan hozzájárulhatnak a dolgozók kifáradásához, kiégettségéhez, ami elvándorláshoz és létszámcsökkenéshez vezethet.

Vizsgálatunk folytatásának és kiegészítésének - az együttérzésből eredő kifáradást és elégedettséget mérő ProQOL kérdőív validálásával - célja, hogy a multidiszciplináris teamtagok válaszainak további elemzésével felderítsük a szakterületek közötti hasonlóságokat és különbözőségeket, összevessük a homogén szakmacsoportok és az egészségügy más területein tevékenykedők adataival, valamint, hogy nagyobb figyelmet fordítsunk a dolgozók és a páciensek közötti kapcsolat feltérképezésére. Ez a klinikai gyakorlatban lehetőséget adhat a megküzdés segítésében: a speciális megterhelések figyelembevételével a megfelelő támogatási programok kialakításában.

Anyagi támogatás: A cikk megírása anyagi támogatásban nem részesült.

Szerzői munkamegosztás: R. E.: Problémafelvetés, a statisztikai adatok elemzése, az eredmények értékelése. K. A., Z. A.: Aktív részvétel a háttérirodalom összegyưjtésében, a tanulmány írásában, az eredmények értékelésében. H. K.: Aktív részvétel a háttérirodalom összegyưjtésében, szakértői részvétel az eredmények értelmezésében és a tanulmány végleges formájának kialakításában. A cikk végleges változatát valamennyi szerző elolvasta és jóváhagyta.

Érdekeltségek: A szerzőknek nincsenek érdekeltségeik.

\section{Irodalom}

[1] Hegedus, K.: The mental health of the staff dealing with dying patients. The possibilities of decreasing burnout and mental burdens. [A haldokló betegeket kísérő személyzet mentálhigiénéje. A kiégés és a pszichés terhek csökkentésének lehetőségei.] Lege Artis Medicinae, 2000, 10(5), 448-452. [Hungarian]

[2] Hegedüs, K., Riskó, Á., Mészáros, E.: The physical and mental state of health workers dealing with seriously ill patients. [A súlyos betegekkel foglalkozó egészségügyi dolgozók testi és lelkiállapota.] Lege Artis Medicinae, 2004, 14(11), 786-793. [Hungarian]

[3] Szabó, N., Szabó, G., Hegedüs, K.: Interdisciplinarity - workplace stress - holistic point of view in health care. [Interdiszciplinaritás, 
munkahelyi stressz, holisztikus szemléletû ellátás.] Lege Artis Medicinae, 2008, 18(3), 243-249. [Hungarian]

[4] Kovács, M., Kovács, E., Hegedüs, K.: Is emotional dissonance more prevalent in oncology care? Emotion work, burnout and coping. Psycho-Oncology, 2010, 19(8), 855-862.

[5] Kovács, M., Kovács, E., Hegedüs, K.: Emotion work and burnout: cross-sectional study of nurses and physicians in Hungary. Croat. Med. J., 2010, 51(5), 432-442.

[6] Kegye, A., Zana, Á., Révay, E., et al.: The real cost of caring for seriously ill patients - Compassion fatigue or satisfaction. [A súlyos betegek ellátásának igazi ára - az együttérzésből fakadó fáradtság vagy elégedettség.] Lege Artis Medicinae, 2015, 25(3), 129-136. [Hungarian]

[7] Figley, C. R.: Compassion fatigue: Psychotherapists' chronic lack of self care. J. Clin. Psychol., 2002, 58(11), 1433-1441.

[8] Melvin, C. S.: Professional compassion fatigue: what is the true cost of nurses caring for the dying? Int. J. Palliat. Nurs., 2012, $18(12), 606-611$.

[9] Kopp, M., Kovács, M.: Appendix: Questionnaires used in the Hungarostudy 2002 survey. In: Kopp, M., Kovács, M. (eds.): Quality of life of the Hungarian population in the millenary. [Melléklet: a Hungarostudy 2002 felmérésben használt kérdőívek. In: Kopp, M., Kovács, M. (szerk.): A magyar népesség életminősége az ezredfordulón.] Semmelweis Kiadó, Budapest, 2006. [Hungarian]

[10] Kopp, M., Rózsa, S., Skrabski, Á.: Questionnaires used in the Hungarostudy 2002 survey and Hungarostudy 2006 follow-up study. In: Kopp, M. (ed.): Hungarian state of mind 2008. [A Hungarostudy 2002 és a Hungarostudy 2006 követéses vizs- gálat kérdőívei. In: Kopp, M. (szerk.): Magyar lelkiállapot, 2008.] Semmelweis Kiadó, Budapest, 2008. [Hungarian]

[11] Susánszky, É., Székely, A.: The metodology of the Hungarosudy 2013 survey. In: Susánszky É., Szántó, Zs. (eds.): Hungarian state of mind 2013. [A Hungarostudy 2013 felmérés módszertana. In: Susánszky, É., Szántó, Zs. (szerk.): Magyar lelkiállapot, 2013.] Semmelweis Kiadó, Budapest, 2013. [Hungarian]

[12] Zana, Á., Hegedús, K., Szabó, G.: Validity and reliability of Multidimensional Fear of Death Scale in Hungarian population. [A Neimeyer és Moore-féle Multidimenzionális Halálfélelem Skála validálása magyar populáción.] Mentálhigiéné és Pszichoszomatika, 2006, 7(3), 257-266. [Hungarian]

[13] Czeglédi, E.: Options of stress management in obesity treatment. [A stresszkezelés alkalmazási lehetőségei az elhízás kezelésében.] Orv. Hetil., 2016, 157(7), 260-267. [Hungarian]

[14] Pikó, B. F.: Burnout, role conflict, job satisfaction and psychosocial health among Hungarian health care staff: a questionnaire survey. Int. J. Nurs. Stud., 2006, 43(3), 311-318.

[15] Kalicińska, M., Chylińska, J., Wilczek-Rożyczka, E.: Professional burnout and social support in the workplace among hospice nurses and midwives in Poland. Int. J. Nursing Pract. 2012, $18(6), 595-603$.
(Zana Ágnes dr., Budapest, Nagyvárad tér 4., 1089 e-mail: zanagi72@gmail.com

\section{Szakorvosi Állás}

A Szent Margit Rendelöintézet szemész szakorvost keres munkaviszonyban, vagy vállalkozói szerződéssel, teljes munkaidőben.

Fényképes önéletrajzot a következő email címre várjuk: thomka.gyorgy@obudairendelok.hu 